DOI: https://doi.org/10.31933/dijms.v3i3

Received: 23 November 2021, Revised: 25 December 2021, Publish: 15 January 2022

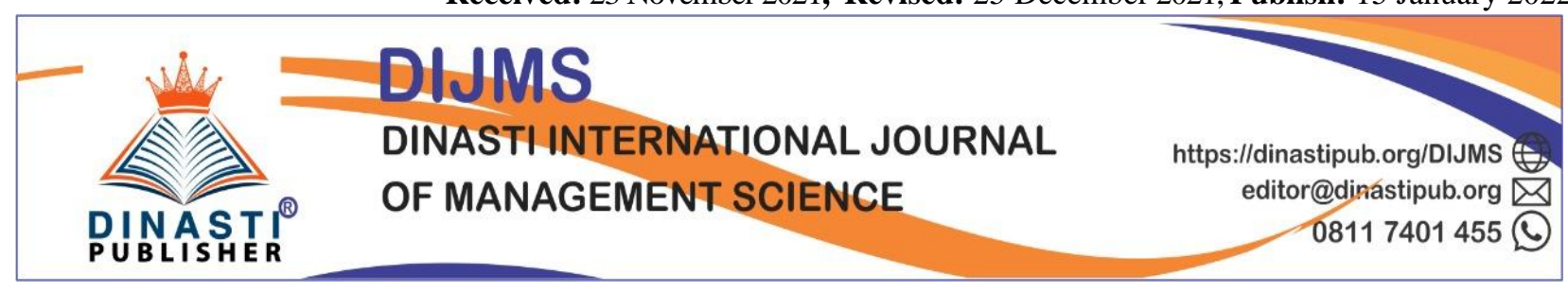

\title{
THE EFFECT OF HALAL LABELS, BRANDS, AND PRICES ON OVER THE COUNTER DRUGS PURCHASE DECISION IN WEST JAVA PROVINCE DURING COVID-19
}

\author{
Muhammad Iqbal Ismail ${ }^{1}$, Maya Sova ${ }^{2}$, Nandan Limakrisna ${ }^{3}$ \\ ${ }^{1)}$ University of Persada Indonesia Y.A.I, Jakarta, Indonesia, Iqbalismail1771@ gmail.com \\ ${ }^{2}$ University of Persada Indonesia Y.A.I, Jakarta, Indonesia \\ ${ }^{3)}$ University of Persada Indonesia Y.A.I, Jakarta, Indonesia
}

Corresponding Author: Muhammad Iqbal Ismail

\begin{abstract}
This study aims to determine whether the halal label, brand, and price variables affect consumers' decision to purchase over-the-counter drugs in the province of West Java during the covid-19 pandemic. The research sample amounted to 200 people. Sampling used a survey method with a data collection tool in the form of a questionnaire through a google form, measured using a Likert scale. The questionnaire was tested using validity and reliability tests. From the results of research with descriptive analysis, regression analysis prerequisite test, multiple linear regression test, and hypothesis testing using the SPSS version 25 program, it is known that there is a significant influence of independent variables halal label, brand, and price on the dependent variable purchasing decisions of over-the-counter drugs in West Java province during the covid-19 pandemic.
\end{abstract}

Keywords: Halal Label, Brand, Price, Over-the-counter drug, West Java, Covid-19.

\section{INTRODUCTION}

The outbreak of the disease caused by the coronavirus (COVID-19) is a threat to the health and life of the world's population. Many people's consumption behavior has changed. Many people stockpile medicine, health supplies, and food (Miri et al., 2020). People are fearful of experiencing health problems such as acute breathing due to being exposed to the Covid 19 virus (Severo, De Guimarães, \& Dellarmelin, 2021). West Java is a province with large 35,377.76 km2, with the most significant number of Muslims in Indonesia, 41,314,121 people or $83.77 \%$ of the total population who embrace Islam (Indonesian Central Bureau of Statistics, 2020). The vast area of West Java and many people make health needs also increase, one of which is the need for medicines. 
The drug market is divided into two sectors: the prescription drug market (generic drugs, branded generics, and patented drugs) and the non-prescription drug market (over-the-counter or non-prescription drugs). The global pharmaceutical market is growing at an average of $10 \%$ per year (during 2011-2015). In Indonesia, prescription drugs contributed about $62 \%$ of the national pharmaceutical market in 2015 and the remaining $38 \%$ of the over-the-counter drug market. With a population of $18.39 \%$ of the total population of Indonesia, it is estimated that the over-the-counter drug market in West Java in 2020 will reach 7.13 trillion (Industry Update, 2016).

Central Bureau of Statistics survey in 2017-2019 regarding self-medication in the West Java region reached $73.32 \%$ (West Java Statistics Agency, 2020). Over-the-counter drug products are one of the people's choices in self-medication. With the majority of the Muslim population in West Java, it is hoped that the medicinal products used are guaranteed to be halal. Halal products can be consumed or used according to Islamic religious orders, which are obligatory. One indicator of halal products is the presence of halal labels on drug packaging (Ministry of Religion, 2003). The problem of consumers in choosing products other than the halal label is the brand and price. A brand is a sign, name, symbol, design, term, or a combination of these, which is used to distinguish it from competitors in identifying the product or service of the seller (Kotler \& Keller, 2012). Besides, price is also a determinant of consumer purchasing decisions. Price is the value of several means of exchange (money) given by consumers for owning or using the product or service for the benefits they get. Prices rise because of the value charged for a product or service (Kotler \& Armstrong, 2008).

\section{Formulation of the problem}

Based on the description in the introduction, the problems in this study can be formulated, namely:

1. How significant is the influence of the halal label on the decision to buy over-the-counter drugs in the province of West Java during the covid-19 pandemic.

2. How significant is the influence of the brand on the decision to buy over-the-counter drugs in the province of West Java during the covid-19 pandemic.

3. How significant is the influence of price on the decision to buy over-the-counter drugs in the province of West Java during the covid-19 pandemic.

4. Descriptive analysis of the influence of demographics (gender, age, occupation, religion, and the amount of monthly expenditure) on the factors that influence consumers in the decision to purchase over-the-counter drugs.

\section{Research purposes}

This study was conducted to explain whether there is an influence of the halal label, brand, and price factors on the decision to purchase over-the-counter drugs in the province of West Java during a covid-19 pandemic. In addition, a descriptive analysis was also conducted to see whether there was an influence of demographics (gender, age, occupation, religion, and the amount of 
monthly expenditure) on the factors that influence consumers in purchasing decisions of over-thecounter drugs.

\section{LITERATURE REVIEW}

According to Health Law no. 36 of 2009, a drug is a substance or a combination of materials, including biological products, which are used to influence or investigate physiological systems or pathological conditions in the context of establishing a diagnosis, prevention, healing, recovery, health promotion, and contraception, for humans.

Over-the-counter drugs can be purchased without using a doctor's prescription at pharmacies or drug stores. This drug has been widely proven to have no risk of alarming danger as long as it is used according to its rules, so it is relatively safe. They are used to prevent and treat minor illnesses that can be done by the patient alone or are often called self-medication-for example, vitamin B complex, paracetamol, vitamin C, antacids, and others.

Labels are from English "label," which means "name" or to give a name. In the Big Indonesian Dictionary, a label is defined as a paper, cloth, metal, wood, etc. Attached to goods that explain the name of the goods, owner's name, destination, address, and so on (Phoniex Library, 2012). According to Islam's teachings, the word halal comes from Arabic, namely halla, yahillu, and hillan. In a book entitled At-Ta'rifat written by Al-Jurjani, the word halal is defined as an act permitted by Islamic law to use objects or anything needed to fulfill physical needs, including food, drink, and medicine. -medicine (Ritonga, 2001).

The brand is an attribute that has benefits, values, cultural interpretations, and personality used to remember a product (Kotler, 2000). Branded drugs are drugs with the manufacturer's trade name, divided into two categories, among others: patent drugs, namely drugs that have just been discovered based on research and are branded according to the company that invented them, usually having a patent period of 20 years. The second is branded generic drugs, namely drugs whose patents have expired and are named according to the company that produces them. If the company that owns the patent is still producing and selling drugs whose patent period has expired, the product is often referred to as a generic branded drug "me too" (Sampurno, 2011).

The Price is the monetary value of an item. In more detail, the price is defined as the amount of value that consumers exchange to get the benefits of the goods or services that he buys, which is an element of the marketing mix that generates income while other elements incur costs. Therefore, the price will affect the level of sales, market distribution and will ultimately determine the level of company profits (Kotler \& Armstrong, 2008).

Purchasing decisions are defined as a solution to a problem of human activity to meet their needs by buying a specific product or service, starting from recognizing their needs, seeking 
information related to their needs, evaluating several choices to deciding to buy, and their behavior after buying. (Swasla \& Handoko, 2000).

Over-the-counter medicines can be purchased at general pharmacies, special referral pharmacies, pharmacies in hospital pharmacy installations, or licensed drug stores. Over-thecounter medicines can be purchased without using a doctor's prescription so that patients are freer to choose the desired product, such as products with unique labels (halal), brands, and choices of more affordable prices. This follows Indonesian government regulations No. 51 of 2019 concerning Pharmaceutical Work, Law No. 33 of 2014 concerning Guaranteed Halal Products, and Law No. 8 of 1999 concerning Consumer Protection. Several factors need to be considered in drug purchasing decisions: type of disease, condition and physical body, medicinal products, and side effects of drugs (Widodo, 2004).

\section{Previous research}

The studies that have been carried out related to halal labels include Saleha Sadeeqa et al., to assess knowledge, attitudes \& perceptions about halal medicines among the general public in Penang, Malaysia. 458 Muslims aged 18 years and over to read and understand Malay were included. This study found positive perceptions about halal medicines. Almost all respondents scored $50 \%$ and above. More than $90 \%$ of respondents feel that patients have the right to get information about the source of the ingredients of the drugs prescribed to them. Most respondents agree that drug companies must mark drug packaging with a halal or non-halal logo. If drug manufacturers mark the halalness of their products, then people will choose it because it is considered better for them. The majority of respondents think that the public should be more educated about the halalness of drugs, besides that doctors or pharmacists must inform their patients about illicit ingredients in drugs. The majority of respondents support seeking direction from religious leaders regarding the use of drugs (Sadeeqa et al., 2013).

Research related to halal labels on drugs was also carried out by Noorizan Abdul-Aziza et al., who stated that information about the ingredients in drugs was the most contributing factor to the halal status of drugs. From the survey results, it was found that $65 \%$ of drug products were not found halal logo in hospital. Therefore, pharmaceutical manufacturers and health care professionals are expected to use halal drugs proactively. Information about halal and haram in medicinal products is expected to protect consumers from non-halal ingredients (Abdul-Aziza et al., 2014).

The halal label on drugs was also investigated by Marina Kawaguchi-Suzuki et al., who stated that it is essential to understand and respect culture to enrich interactions in society. Religious beliefs, sentiments, or ethnocentricity have formed social norms and values essential in buying halal drugs. Health practitioners must give patients the freedom to choose halal drugs. Thus consumers will feel protected from illicit drug products (Kawaguchi-Suzuki et al., 2019). Another 
study related to halal labeling on drugs was carried out by Sylva Alif Rusmita et al., stating that the majority (99\%) of Islamic Economics students in East Java, Indonesia agreed with the halal logo on drugs. Most respondents knew halal on products, but only some customers always buy halal drugs. It is due to the significant influence of doctors in purchasing drugs and the large number of drug manufacturers who still do not guarantee the halalness of drugs for consumers. The demand for halal drugs can encourage manufacturers to create alternative treatments for Muslims who care about halal (Rusmita et al., 2021).

Research related to over-the-counter drugs was conducted by Indriyani Rafiqa, who stated that in the decision-making process to purchase over-the-counter drugs in Jakarta, seven factors influence consumers, namely brand, availability, price, effectiveness, promotion, safety, guarantee, and packaging design. These factors found that brand is the most influential factor and packaging design is the lowest influence (Rafiqa, 2012). Another study related to factors that influence consumers' purchasing decisions of over-the-counter drugs was conducted in Jaipur, India, by Dadhich and Dixit. In this study, it is known that the most influential factor is the brand of the product. Consumers know this brand through advertisements on television (Dadhich \& Dixit, 2017). Another study by Kohli and Buller concluded that the purchase decision factor for over-thecounter drugs in America was strongly influenced by price. While advertising factors, drug effectiveness, disease severity, physical drug form, drug safety, drug's ability to cure several diseases, and companies that produce drugs are considered to affect purchasing decisions, but not as much as the price effect (Kohli \& Buller, 2013). Another study was conducted by Fenny Silviana Rizal et al.. There were 200 respondents in this study. From this study, it was found that the determinants of the decision to purchase over-the-counter drugs were the highest with an average score of above 4, namely efficacy of the drug, speed of the drug in worshiping the disease, side effects of the drug, severity of the pain, availability of the drug at the nearest outlet, affordable cost, and dose - drugs, advice from family or friends, how to take drugs, drug manufacturers. Then the factors that are in the middle position with a score above 3 to less than 4 are advice from pharmacists, diversity of medicinal properties, advertising, packaging design, and taste of the drug, for factors that are in the lower position with a score of 1 to less than 3 , namely the presence of a gift (gimmick) when purchasing over-the-counter drugs (Rizal et al., 2019).

The highest population and a large number of Muslim populations in West Java are considered capable of representing the composition of Indonesian society. As a complement to the data analysis, the researcher also looked at the respondents' age, gender, occupation, last education level, average monthly expenditure, religion, frequency of buying over-the-counter drugs in the last three months, and where to buy over-the-counter drugs.

\section{RESEARCH METHODS}

The method used in this research is quantitative research. The causal relationship was investigated and calculated to determine how much influence the halal label, brand, and price 
factors had on the decision to purchase over-the-counter drugs in the province of West Java during the Covid-19 pandemic. Research time from January to December 2021.

\section{Variables and Operational Definitions}

1. The halal label states that the over-the-counter drug product in question has obtained the MUI halal certificate does not contain haram materials or elements, and their processing follows Islamic religious law.

2. A brand is the name, logo, or other attributes attached to over-the-counter drug products.

3. Price is the amount of value in monetary terms, which consumers exchange for the benefits of buying over-the-counter drug products.

4. The purchase decision is the final choice of the buyer for over-the-counter drug products needed for disease control with specific considerations.

\section{Research Instruments}

Researchers use it as a guide in collecting data so that the process becomes more accessible and more systematic (Arikunto, 2010). There are two sources of data in this study, and the first is secondary data sources obtained from books, documentation, journals or other official news sources in the media. The second source is primary data obtained from direct surveys to respondents in the form of a questionnaire conducted online with the help of a google form. The population in this study were all people who had bought over-the-counter drugs in West Java, and the samples were people with diabetes15-64 years old who bought over-the-counter drugs in the last three months. It was chosen so that the data obtained were more targeted and that age was a productive age who could make decisions independently (Ministry of Health, 2020).

The sampling in this study will use a non-probability sampling method, namely a sampling technique using specific characteristics as a basis for generalization (Sugiyono, 2009). The number of samples is calculated by multiplying the minimum sample by five times from the number of indicators and the maximum sample by ten from the number of research indicators so that the minimum sample is $5 \times 20=100$ and the maximum sample is 10x20=200 (Augusty, 2006). Regarding the above formulation, for the good results of this research, maximum sizes are used as the number of samples needed in this study, namely 200 respondents. The variables to be measured are formed into variable indicators by measuring the Likert scale. This indicator will be used to formulate questions and statements on the questionnaire.

\section{Data analysis method}

The data that has been collected is processed and analyzed using codifying the data, if the data, and concluding it. The methods used in data analysis in this research are validity test, reliability test, descriptive analysis, regression analysis prerequisite test, multiple linear regression test, and hypothesis testing as follows (Ghozali, 2018): 
1. A validity test was conducted to test the accuracy of the questions and statements on a questionnaire, qualified if the number was more than 0.3. Pearson moment correlation was used in this study with the help of SPSS version 25.

2. The reliability test was conducted to test the reliability of the questions and statements in the questionnaire. Cronbach's alpha formula is used to measure it with the help of SPSS version 25. If the alpha coefficient is more significant than 0.6, a question and statement are declared reliable.

3. Regression analysis prerequisite tests include:

a) The normality test was carried out to determine the normality of the distribution of the processed data. The Kolmogorov - Smirnov method is used to test the normality of the data by visualizing it using the P-Plot of Regression Standardized Residual graph. The significant criteria if the value obtained $>0.05$ means that the data is usually distributed; if the value obtained is $<0.05$, the data is not normally distributed.

b) The multicollinearity test was conducted to determine the possibility of deviations from the linear relationship between the independent variables in the regression model. Passing the multicollinearity test is a prerequisite before the regression test is performed. The regression coefficient cannot be determined if multicollinearity and the standard error cannot be interpreted significantly. If the tolerance value produces a value $>0.05$ or the variance influence factor produces a value $<0.05$, then multicollinearity does not occur. If multicollinearity occurs, then the independent variable must be eliminated.

c) A heteroscedasticity test was conducted to test the possibility of variance inequality from residual observations to other observations. The heteroscedasticity test was carried out by the park, plot graph, white, and glejser test. The test in this study uses a graph plot between the predicted value of the dependent variable, namely ZPRED, and the residual SRESID. The points that spread above and below number 0 on $\mathrm{Y}$-axis and the absence of a clear pattern indicate no heteroscedasticity.

d) The linearity test of the regression line was conducted to determine the significant linear relationship between variables. Multiple linear regression analyses can be performed if the tested data is linear. However, if not, then non-linear regression analysis is used. The linearity significance value was calculated to ensure the linearity of the data. If Deviation from Linearity $>0.05$, then the relationship between the dependent variable and the independent variable is linear, and Deviation from Linearity $<0.05$ describes the relationship between the dependent variable and the independent variable is non-linear.

4. Descriptive analysis was conducted to see the condition of the respondents who were sampled with certain characteristics consisting of; respondent's age, gender, occupation, education level, monthly expenditure, religion, frequency of purchasing over-the-counter drugs during COVID-19, and where to buy it. Numerical descriptive was used in this study to make the analysis easier, with the following stages: Respondent data was made in a distribution table, the answers were added up for each respondent, processed by the formula: the number divided by the total score multiplied by $100 \%$. 
5. Multiple linear regression test is a test carried out to see the linear relationship between the independent variables (X1, X2, and X3) and the dependent variable (Y), whether it has a positive or negative relationship with the following formula:

$\mathrm{Y}=\beta 0+\beta 1 \mathrm{X} 1+\beta 2 \mathrm{X} 2+\beta 3 \mathrm{X} 3+\varepsilon$

Information: $\mathrm{Y}=$ Decision to buy over-the-counter drugs, $\mathrm{X} 1=$ Halal label, $\mathrm{X} 2=\mathrm{Brand}, \mathrm{X} 3=$ Price, $\beta 0=$ Constant, $\beta 1 \beta 2 \beta 3=$ Regression coefficient, $\varepsilon=$ Error term.

6. Hypothesis testing is a temporary answer from a study which is usually stated in the form of an analysis statement carried out with the help of SPSS version 25, including:

a) The coefficient of determination test (R2) was carried out to measure the level of the model's ability to explain variations in the dependent variable. The ability of the independent variables to explain the variation of the dependent variable is minimal if the coefficient of determination is small. The independent variables provide almost all the information needed to predict the dependent variable's variation if its value is close to one.

b) A simultaneous test (F-Stat) was conducted to determine whether the independent variables (X1, X2, and X3) in a study had a significant simultaneous effect on the dependent variable (Y) or not. In addition, this test is also used to determine the regression model used in predicting the dependent variable. The probability value of F-Stat $0.05(5 \%)$ shows that the independent variable has a significant simultaneous effect on the dependent variable and vice versa.

c) A partial test (T-Stat) was conducted to determine the partially significant effect of the independent variables (X1, X2, and X3) on the dependent variable (Y). The independent variables in this study significantly affect the dependent variable if the t-count $>\mathrm{t}$-table, or if the probability value is $0.05(5 \%)$ and vice versa.

d) Paired T-test (T-paired) was conducted to test the average similarity of independent populations, i.e., one population is not related or not influenced by other populations. Population diversity is not known with certainty because lack of information is the most common condition encountered in a study. Therefore, the t-test (1 sample, two samples, independent, or paired) is a method that is often used.

\section{FINDINGS AND DISCUSSION}

Table 1. Description Test Results

a. Description by Gender

\begin{tabular}{|l|c|c|}
\hline \multicolumn{1}{|c|}{ Gender } & Total & Percentage \\
\hline Male & 80 & $40 \%$ \\
\hline Female & 120 & $60 \%$ \\
\hline Grand Total & $\mathbf{2 0 0}$ & $\mathbf{1 0 0 \%}$ \\
\hline
\end{tabular}

b. Description by Age

\begin{tabular}{|l|c|c|}
\hline \multicolumn{1}{|c|}{ Age } & Total & Percentage \\
\hline a. $15-24$ & 48 & $24 \%$ \\
\hline b. $25-40$ & 107 & $54 \%$ \\
\hline c. $41-56$ & 39 & $20 \%$ \\
\hline
\end{tabular}

e. Description by Monthly Expenses

\begin{tabular}{|c|c|c|}
\hline Monthly expenses & Total & Percentage \\
\hline a. $<\operatorname{Rp} 2.500 .000$ & 66 & $33 \%$ \\
\hline b. Rp 2.500.001-Rp 5.000.000 & 85 & $43 \%$ \\
\hline c. Rp 5.000.001-Rp 7.500.000 & 24 & $12 \%$ \\
\hline d. $>7.500 .000$ & 25 & $13 \%$ \\
\hline Grand Total & 200 & $100 \%$ \\
\hline \multicolumn{3}{|c|}{ f. Description by Religion } \\
\hline Religion & Total & Percentage \\
\hline a. Islam & 190 & $95 \%$ \\
\hline
\end{tabular}




\begin{tabular}{|c|c|c|}
\hline d. $57-64$ & 6 & $3 \%$ \\
\hline Grand Total & 200 & $100 \%$ \\
\hline \multicolumn{3}{|c|}{ c. Description by Profession } \\
\hline Profession & Total & Percentage \\
\hline a. Student & 29 & $15 \%$ \\
\hline b.Government employees & 40 & $20 \%$ \\
\hline c. private employees & 69 & $35 \%$ \\
\hline d. Others & 62 & $31 \%$ \\
\hline Grand Total & 200 & $100 \%$ \\
\hline
\end{tabular}

d. Description by Educational Background

\begin{tabular}{|l|c|c|}
\hline \multicolumn{1}{|c|}{ Educational background } & Total & Percentage \\
\hline a. Elementary/Jr/SR & 82 & $41 \%$ \\
\hline b. Diploma & 21 & $11 \%$ \\
\hline c. Undergraduate & 84 & $42 \%$ \\
\hline d. Postgraduate & 13 & $7 \%$ \\
\hline Grand Total & $\mathbf{2 0 0}$ & $\mathbf{1 0 0 \%}$ \\
\hline
\end{tabular}

\begin{tabular}{|l|c|c|} 
b. Christian & 7 & $4 \%$ \\
\hline c. Hindu & 2 & $1 \%$ \\
\hline d. Buddhism & 1 & $1 \%$ \\
\hline Grand Total & $\mathbf{2 0 0}$ & $\mathbf{1 0 0 \%}$ \\
\hline
\end{tabular}

g. Description by Purchase Frequency

\begin{tabular}{|l|c|c|}
\hline \multicolumn{1}{|c|}{ Purchase frequency } & Total & Percentage \\
\hline a. 1 time & 76 & $38 \%$ \\
\hline b. 2-3 times & 84 & $42 \%$ \\
\hline c. 4-5 times & 19 & $10 \%$ \\
\hline d. > 5 times & 21 & $11 \%$ \\
\hline Grand Total & $\mathbf{2 0 0}$ & $\mathbf{1 0 0 \%}$ \\
\hline
\end{tabular}

h. Description by Place of Purchase

\begin{tabular}{|l|c|c|}
\hline \multicolumn{1}{|c|}{ Place of purchase } & Total & Percentage \\
\hline a. Pharmacy & 158 & $79 \%$ \\
\hline b. Drug store & 17 & $9 \%$ \\
\hline d. Online Pharmacy/ Drug store & 16 & $8 \%$ \\
\hline e. Others & 9 & $5 \%$ \\
\hline Grand Total & $\mathbf{2 0 0}$ & $\mathbf{1 0 0 \%}$ \\
\hline
\end{tabular}

Table 2. Validity Test Results

Halal Label

\begin{tabular}{|c|c|c|c|}
\hline Indicator & Pearson Correlation & $\mathrm{N}$ of items & Description \\
\hline Purchase because of the halal label & 0.628 & 30 & Valid \\
\hline Label as a guarantee of halal products & 0.721 & 30 & Valid \\
\hline Confidence in the impact of halal products & 0.763 & 30 & Valid \\
\hline Perception of halal label & 0.834 & 30 & Valid \\
\hline Halal certification perfection & 0.563 & 30 & Valid \\
\hline \multicolumn{4}{|c|}{ Brand } \\
\hline Indicator & Pearson Correlation & $\mathrm{N}$ of items & Description \\
\hline Brand reputation & 0.380 & 30 & Valid \\
\hline Known brand & 0.588 & 30 & Valid \\
\hline Memorable brand & 0.744 & 30 & Valid \\
\hline Interesting brand & 0.722 & 30 & Valid \\
\hline Brand with gimmick & 0.753 & 30 & Valid \\
\hline \multicolumn{4}{|c|}{ Price } \\
\hline Indicator & Pearson Correlation & $\mathrm{N}$ of items & Description \\
\hline Price considerations & 0.545 & 30 & Valid \\
\hline Product competitiveness & 0.645 & 30 & Valid \\
\hline Price match with quality & 0.640 & 30 & Valid \\
\hline Alignment with benefits & 0.623 & 30 & Valid \\
\hline Price Variations & 0.483 & 30 & Valid \\
\hline \multicolumn{4}{|c|}{ Buying decision } \\
\hline Indicator & Pearson Correlation & $\mathrm{N}$ of items & Description \\
\hline
\end{tabular}




\begin{tabular}{llll}
\hline The influence of trust & 0.696 & 30 & Valid \\
The influence of brand recommendations & 0.594 & 30 & Valid \\
Affect of affordability & 0.419 & 30 & Valid \\
Product need & 0.517 & 30 & Valid \\
Benefits of the product & 0.641 & 30 & Valid \\
\hline
\end{tabular}

Table 3. Reliability Test Results

\begin{tabular}{|c|c|c|c|}
\hline Variable & Cronbach's Alpha & $\mathbf{N}$ of items & Description \\
\hline Halal label & 0.777 & 30 & Reliable \\
\hline Brand & 0.757 & 30 & Reliable \\
\hline Price & 0.719 & 30 & Reliable \\
\hline Buying decision & 0.715 & 30 & Reliable \\
\hline
\end{tabular}

Table 4. Normality Test Results

\begin{tabular}{clc} 
Test Name & Result Asym.Sig (2-Tailed ) & \multicolumn{1}{c}{ Description } \\
Kolmogorov-Smirnov . test & 0.190 & Data is normally distributed
\end{tabular}

Table 5. Multicollinearity Test Results

\begin{tabular}{lccc}
\hline \multicolumn{1}{c}{ Independent Variable } & VIF & Tolerance & Description \\
Halal label & 1.112 & .899 & No multicollinearity \\
Brand & 1,599 & .626 & No multicollinearity \\
Price & 1.503 & .665 & No multicollinearity \\
\hline
\end{tabular}

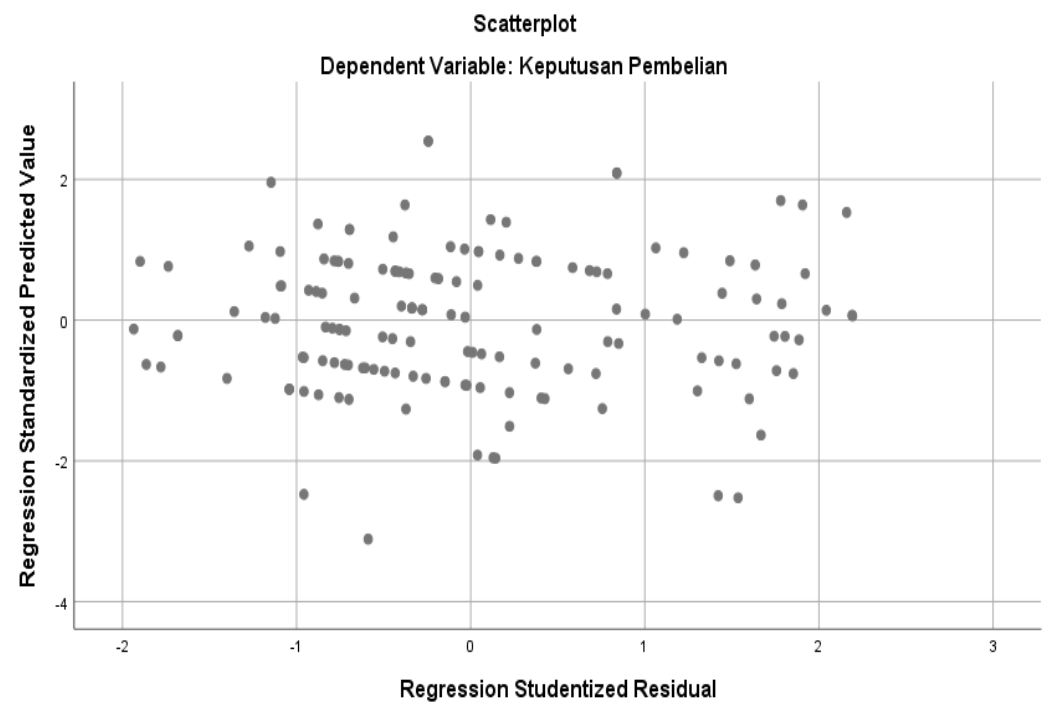

Figure 1. Scatterplot Graph of Test Results Heteroscedasticity

Table 6. Linearity Test Results

\begin{tabular}{ccc}
\hline Independent Variable & Deviation from Linearity & Description \\
Halal label & .997 & Relationship between linear variables \\
\hline
\end{tabular}




\begin{tabular}{ccl}
\hline Brand & .597 & Relationship between linear variables \\
Price & .907 & Relationship between linear variables \\
\hline
\end{tabular}

Based on the research that has been done, it is known that the test of the validity of the statements and statements in the questionnaire the calculated $r$-value is greater than the critical $r$ (> 0.3 ), it can be concluded that all indicators in the research questionnaire are declared valid, and the reliability test results are known that the arithmetic value is more significant than alpha Cronbach (>0.60) so that the research instrument is declared reliable. Regression analysis prerequisite test is also known to meet the requirements of normality test, multicollinearity test, heteroscedasticity test, and regression line linearity test.

Table 7. Multiple Linear Regression Test Results and Hypothesis Testing

\begin{tabular}{|c|c|c|c|c|}
\hline \multirow{2}{*}{ Test type } & \multicolumn{3}{|c|}{ Mark } & \multirow{2}{*}{ Results } \\
\hline & Halal label & Brand & Price & \\
\hline Multiple linear regression & 0.421 & 0.276 & 0.256 & $\begin{array}{c}\mathrm{Y}=1.211+0.421 \mathrm{X} 1+0.276 \mathrm{X} 2+ \\
0.256 \mathrm{X} 3+\varepsilon\end{array}$ \\
\hline Coefficient of determination (R2) & \multicolumn{3}{|c|}{.808} & $\begin{array}{l}\mathrm{X} 1, \mathrm{X} 2 \text {, and } \mathrm{X} 3 \text { have an effect of } \\
80.8 \% \text { on } \mathrm{Y}\end{array}$ \\
\hline Simultaneous test (F-Stat) & \multicolumn{3}{|c|}{275,806} & $\begin{array}{l}\mathrm{X} 1, \mathrm{X} 2 \text {, and X3 affect Y linearly } \\
\text { significantly }\end{array}$ \\
\hline Partial Test (T-Stat) & 12,230 & 7,539 & 6,486 & $\mathrm{H} 1, \mathrm{H} 2, \mathrm{H} 3$ accepted \\
\hline Paired T test (T-Paired) & .000 & .000 & .000 & H1, H2, H3 accepted \\
\hline
\end{tabular}

Source: SPSS 25 . Processing Results

\section{Description :}

$\mathrm{X} 1=$ Halal label

$\mathrm{X} 2=\mathrm{Brand}$

$\mathrm{X} 3=$ Price

$\mathrm{Y}=$ Decision to buy over-the-counter drugs

H1 = Halal label has an effect on purchasing decisions

$\mathrm{H} 2=$ Brand has an effect on purchasing decisions

H3 = Price has an effect on purchasing decisions

$\varepsilon \quad=$ Error term

\section{Halal Label Influence Factors}

The halal label factor is very influential on the decision to purchase over-the-counter drugs in the province of West Java during the covid-19 pandemic. It can be confirmed in the results of multiple linear regression analysis with a positive value of the halal label coefficient $(0.421)$, which shows that with every increase in halal labeling on over-the-counter drug products by 1 unit, the purchase decision will increase by the coefficient value if the other variables are constant. Oncoefficient of determination test, the amount of adjusted R2 (coefficient of determination that has been adjusted) in this study is 0.808 , which is positive. In the simultaneous test (F-Stat) at level $=0.05$, the calculated $\mathrm{F}$ value (275.806) is greater than the $\mathrm{F}$ table value (2.26), which can be 
interpreted that the halal label, brand, and price simultaneously affect the decision to purchase over-the-counter drugs in the province of West Java during covid-19.

In the partial test (T-Stat) and the paired T-test (T-paired), the halal label variable has a tcount value of 12.230, greater than t-table 1.65251 and a significance value of 0.000 less than 0.05 . It shows that the halal label has a positive and significant effect on purchasing decisions for overthe-counter drugs in the province of West Java at a significance level of 5\% or, in other words, the first hypothesis (H1) is accepted from the assessment criteria.

Factors influencing the decision to purchase over-the-counter drugs are high due to a halal label following the data submitted by Saleha Sadeeqa et al. regarding the assessment of knowledge, attitudes \& perceptions of halal medicines in general public in Penang, Malaysia. Most respondents agree that drug companies must mark drug packaging with a halal or non-halal logo. More than $90 \%$ of respondents feel that patients have the right to get information about the source of the ingredients of the drugs prescribed to them. If drug manufacturers mark the halalness of their products, then people will choose it because it is considered better for them. Another study was conducted by Noorizan Abdul-Aziza et al., Marina Kawaguchi-Suzuki et al. also investigated the halal label on drugs, stating that religious beliefs, sentiments, or ethnocentricity have formed social norms and values that play an essential role in the decision-making process to buy halal drugs. Research related to halal labeling on drugs was also carried out by Sylva Alif Rusmita et al., who stated that the majority (99\%) of Islamic Economics students in East Java, Indonesia agreed with the halal logo on drugs.

Given the importance of halal in consumer products, the government has issued Law no. 33 of 2014 concerning Halal Product Guarantee (JPH). In addition, the government has also issued Indonesian government regulations No. 31 of 2019 to implement Law no. 33 of 2014, which regulates that consumption products must be certified halal. However, of the 206 Indonesian pharmaceutical industries in October 2019, only 53 companies have been certified halal, or around $25.7 \%$ of the total pharmaceutical industry in Indonesia. The government still provides concessions to the pharmaceutical industry to include halal labels on their products because there is no agreement between the relevant ministries, and not many pharmaceutical industries have assessed the need for halal labels on medicinal products.

Over-the-counter drugs can be purchased at general pharmacies, special referral pharmacies, pharmacies in hospital pharmacy installations, or licensed drug stores without using a doctor's prescription, so that consumers are more flexible in choosing the desired product, such as products with unique labels (halal), brands, and more affordable price options. This follows Indonesian government regulations No. 51 of 2009 concerning Pharmaceutical Work, Law No. 33 of 2014 concerning Guaranteed Halal Products, and Law No. 8 of 1999 concerning Consumer Protection. 


\section{Brand Influence Factor}

From the study results, the brand factor is also quite influential on the decision to purchase over-the-counter drugs in the province of West Java during the covid-19 pandemic. It can be confirmed in the results of multiple linear regression analysis with a positive brand coefficient value (0.276) which shows that for every 1 unit increase in the brand strength of an over-thecounter drug product, the purchasing decision will increase by the coefficient value if the other variables are constant.

In the partial test (T-Stat) and the paired T-test (T-paired) variable, the brand has a $\mathrm{t}$ count value of 7.539, which is more significant than t table 1.65251, and a significance value of 0.000 less than 0.05 , which indicates that the brand has a positive influence on the decision to purchase over-the-counter drugs in the province of West Java during covid-19 at a significance level of 5\% or in other words the second hypothesis (H2) accepted.

The deciding factor for purchasing over-the-counter drugs due to the influence of brand factors is following the results of research conducted by Indriyani Rafiqa, who stated that in the decision-making process to purchase over-the-counter drugs in Jakarta, a brand is the most influential factor, and packaging design is the least influential. Another study conducted by Dadhich and Dixit stated that the most influential factor in drug purchasing decisions is the brand of the product. Consumers know this brand through advertisements on television.

Branded drugs are regulated in the regulations the Minister of Health of the Republic of Indonesia in 2010 is a drug with a trading name that uses the name belonging to the drug manufacturer that produces it. Branded drugs are divided into two categories, including patent medicine and branded generic drugs. Patent drugs are valid for 20 years; if the company that owns the patent still produces and sells drugs whose patent period has expired, the product is called a generic drug with the brand "me too."

\section{Price Influence Factor}

From the study results, the price factor is also quite influential on the decision to purchase over-the-counter drugs in the province of West Java during the covid-19 pandemic. It can be confirmed in the results of multiple linear regression analysis with a reasonable price coefficient value (0.256) which shows that every increase in the affordability of an over-the-counter drug product by 1 unit, the purchasing decision will increase by the coefficient value if the other variables are constant. In the partial test (T-Stat) and the paired T-test (T-paired), the price variable has a t-count value of 6.486 , more significant than t-table 1.65251, and a significance value of 0.000 less than 0.05 . It shows that the price variable has a positive and significant effect on purchasing decisions for over-the-counter drugs in the province of West Java during covid-19 at a 
significance level of $5 \%$ or, in other words, the third hypothesis (H3) is accepted. From the assessment criteria.

The deciding factor for purchasing over-the-counter drugs due to the influence of the price factor follows the results of research conducted by Kohli and Buller, who concluded that the purchase decision factor for over-the-counter drugs in America is strongly influenced by price. Another study was conducted by Fenny Silviana Rizal et al. From this study, it was found that the determinants of the decision to purchase over-the-counter drugs were the highest, with an average score above 4 , one of which was an affordable price.

The price factor is one of the critical marketing mix factors to be prepared carefully because of its relationship with distribution, promotion, and product. Consumer perceptions are essential to consider in compiling and calculating prices to continue to grow. Prices must be adjusted to the purchasing power of consumers, quality, and specifications of over-the-counter drug products so that they become relevant when in the market. Drug prices are regulated in the Regulation of the Minister of Health Number 98 of 2015 concerning Provision of Information on the Highest Retail Price of Drugs to be a reference for the pharmaceutical industry to determine the price of drugs to be marketed.

\section{CONCLUSION}

This study was conducted to analyze the influence of the halal label, brand, and price factors on the decision to purchase over-the-counter drugs in the province of West Java during the covid19 pandemic, with a total of 200 respondents. With the following conclusions:

1. Halal label factors, brands, and prices affect the decision-making process to purchase over-thecounter drugs in the West Java region during the covid-19 pandemic as evidenced by multiple linear regression tests with the $\mathrm{Y}=1.211+0.421$ Halal Label +0.276 Brand +0.256 Price + $\varepsilon$.

2. In the hypothesis test with the coefficient of determination (R2), it is known that Halal label, brand, and price factors correlated $80.8 \%$ to the decision to purchase over-the-counter drugs in West Java during the covid-19 pandemic with the most significant correlation value on the price factor, then the halal label, and then the brand.

3. In hypothesis testing with F-Stat, T-Stat and T-Paired show that the factors of the halal label, brand, and price strongly influence the decision to purchase over-the-counter drugs in West Java in a linearly effective manner.

\section{Managerial Implications}

Based on the conclusions obtained, there are several recommendations that the author conveys that can be applied, namely:

1. It is known that women mainly do the over-the-counter purchase drugs with an age range of 25-40 years. From the job profile, private employees or entrepreneurs are the ones who buy 
the most over-the-counter drugs. From the last education level, the most who bought over-thecounter drugs were undergraduates. Meanwhile, the profile of respondents with an average monthly expenditure who buys the most over-the-counter drugs is the respondent with a monthly expenditure level IDR 2,500,001 - IDR 5,000,000. The most preferred place to buy over-the-counter drugs by consumers is the pharmacy. After that, the drug store, then pharmacies or online drug stores. Meanwhile, other places (store, minimarket, or supermarket) are the last choice as a place to buy over-the-counter drugs. From the research that has been done, it is also known that the frequency of purchasing over-the-counter drugs in the period of this research (January 2021 - December 2021) in the province of West Java is the most, namely 2-3 times with a total of $42 \%$ of the total respondents, then one time with a total of $38 \%$, next the frequency of purchasing above five times is $11 \%$, and the last $4-5$ times is $10 \%$. The pharmaceutical industry can use this data for planning, strategy, and communication of over-the-counter drug products suitable for these consumers.

2. Manufacturers should consider the halal label, brand, and price factors that influence consumers in their decision to purchase over-the-counter drugs.

3. For the government, the public's desire for halal drugs must be immediately implemented by all pharmaceutical industries without exception by providing consistent and measurable guidance and guidance. In addition, price and brand are quite influential factors as a priority in the decision to purchase over-the-counter drugs. So the government needs to regulate drugs with various brands circulating in the community so that the prices remain affordable.

4. For academics, this research can add new knowledge about consumer behavior in purchasing decisions, especially over-the-counter drugs, to be a reference and reference for further research.

\section{Suggestion}

For further research, the factors obtained can be further tested with multivariate analysis of variance or smart PLS on over-the-counter drug products in circulation to see differences in the variables used as research objects. As for the involvement or involvement in the decision-making process to purchase over-the-counter drugs, the researcher suggests a broader scope and more variables be investigated. So that more comprehensive data can be obtained.

\section{BIBLIOGRAPHY}

Abdul-Aziza, Noorizan et al. (2014). Assessment of the Halal Status of Respiratory Pharmaceutical Products in a Hospital. Procedia-Social and Behavioral Sciences. Vol. 121. P. 158-65.

Afrizal. (2015). Qualitative Research Methods: An Effort to Support the Use of Qualitative Research in Various Disciplines. Jakarta: Rajawali Press

Alma, Burchari. (2014). Marketing Management and Service Marketing. Bandung: Alphabeta.

Arikunto, Suharsimi. (2010). Research Management. Jakarta: Rineka Cipta

Augusty, Ferdinand. (2006). Management Research Methods. Semarang: Diponegoro University Publishing Agency 
Dadhich, Abhishek and Kapaldeep Dixit. (2017). Consumer Selection and Buying Behavior Towards Over The Counter (OTC) Medicine in Jaipur City. Journal of Management Science and Technology 4, No.2 P: 73-82

Ghozali, Imam. (2018). Application of Multivariate Analysis with SPSS 25 Program. Ed. 9. Semarang: Undip Publishing Agency

Indonesian Central Bureau of Statistics. (2020). Indonesian Statistics. Jakarta: BPS Republic of Indonesia

Indonesian Ulama Council Section of Halal Product Facilities and Infrastructure Project, Directorate General of Islamic Community Guidance and Hajj Organisation. (2003). Frequently Asked Questions About Halal Products. Jakarta: Ministry of Religion

Industry Updates. (2016). Pharmaceutical Industry. Volume 22. Ed. November. Jakarta: Bank Mandiri

Kawaguchi-Suzuki, Marina et al. (2019). Cultural Sensitivity and Global Pharmacy Engagement in Asia: India, Indonesia, Malaysia, Philippines, and Vietnam. American Journal of Pharmaceutical Education. P.651-64.

Kohli, Erol \& Allison Buller. (2013). Factors Influencing Consumer Purchasing Patterns of Generic Versus Brand Name Over-The-Counter Drugs. Southern Medical Journal. Vol.106, No.2. P:155-60

Kotler, P. (2000). Marketing Management: Millennium Edition. Jakarta: Pearson Education Asia, Pte, Ltd. and PT Prehallindo

Kotler, P. \& Gerry Armstrong. (2008). Marketing Principles. Jakarta: Erlangga.

Kotler, P \& Kevin Lane Keller. (2012). Marketing Management. 14th ed. New Jersey: Pearson Prentice Hall, Inc

Miri, S.M., Roozbeh, F., Omranirad, A., Alavian, S.M. (2020). Panic of buying toilet papers: a historical memory or a horrible truth? Systematic review of gastrointestinal manifestations of COVID-19. Hepat. Mon. 20 (3)

Nitisusastro, Mulyadi. (2013). Consumer Behavior in Entrepreneurial Perspective. Bandung: Alphabeta

Rafiqa, Indriyani. (2012). Analysis of Factors Affecting Consumers in the Decision Making Process to Purchase Over-the-counter Drugs (Case Study of Consumers in Jakarta). Depok: University of Indonesia

Republic of Indonesia. (2009). Law No. 36 of 2009 concerning Health. Jakarta: RI Jakarta: RI . (2014). RI Law Number 33 of 2014 concerning Halal Product Guarantee. . (2019). Government Regulation No. 31 of 2019 concerning Implementing Regulations of Law No. 33 of 2014. Jakarta: RI . (2020).Indonesia Health Profile 2019. Jakarta: Ministry of Health RI

Ritonga, Rahman. (2001). Encyclopedia of Islamic Law. Fifth Printing. Jakarta: Ichtiar Van Hoeve 
Rizal, Fenny Silviana, et al. (2019). Consumer Decision Factors in Choosing Over-the-counter Drugs in DKI Jakarta Province. School of Business and Economics Prasetiya Mulya University. Indonesia Business Review. Vol.02, No.1. P.43-64

Rusmita, Sylva Alif et al. (2021). Islamic Economic Student's Knowledge and Attitude Toward Halal Pharmacy Products in East Java, Indonesia.Al-Uqud: Journal of Islamic Economics. Vol. 5 Issue 1, January 2021. P.1-15

Sadeeqa, Saleha et al. (2013). Knowledge, Attitude and Perception Regrading Halal Pharmaceuticals among General Public in Malaysia. International Journal of Public Health Science (IJPHS).Vol.2, No.4, December 2013, P. 143-50

Sampurno. (2011). Pharmaceutical Marketing Management. Yogyakarta: Gadjah Mada University Press

Severo, E. A., De Guimarães, J. C. F., \& Dellarmelin, M. L. (2021). Impact of the COVID-19 pandemic on environmental awareness, sustainable consumption and social responsibility: Evidence from generations in Brazil and Portugal. Journal of Cleaner Production, 286(xxxx). https://doi.org/10.1016/j.jclepro.2020.124947

Somad and Priansa. (2014). Communication Management Develop Customer Oriented Business. Bandung: Alphabeta

Swasla, Basu and T Hani Handoko. (2000). Marketing Management Analysis and Consumer Behavior. Yogyakarta:Bhakti Profesindo

Phoniex Library Team. (2012). Complete Dictionary of Indonesian New Edition. 6th Printing. Jakarta: Media Pustaka Phoenix

West Java Statistics Agency. (2020). West Java Province in Figures. Taken from the Central Bureau of Statistics of West Java:https://jabar.bps.go.id

Widodo, R. (2004). Family Guide to Choosing and Using Medication. Yogyakarta: Discourse Creation 